\title{
Effect of Injection Parameters: Injection Timing and Injection Pressure on the Performance of Diesel Engine Fueled with Palm Oil Methyl Ester
}

\author{
Mahantesh M. Shivashimpi ${ }^{1}$, N. R. Banapurmath ${ }^{2 *}$, S. A. Alur ${ }^{1}$, S. V. Khandal ${ }^{2}$ \\ ${ }^{1}$ Department of Mechanical Engineering, Hirasugar Institute of Technology, Nidasoshi, Karnataka, INDIA \\ ${ }^{2}$ Department of Mechanical Engineering, KLE Technological University, B. V. B. Campus, Hubballi, Karnataka, \\ INDIA
}

\section{*Corresponding Author: nr_banapurmath@rediffmail.com}

Citation: Shivashimpi, M. M., Banapurmath, N. R., Alur, S. A. and Khandal, S. V. (2019). Effect of Injection Parameters: Injection Timing and Injection Pressure on the Performance of Diesel Engine Fueled with Palm Oil Methyl Ester. European Journal of Sustainable Development Research, 3(2), em0077. https://doi.org/10.20897/ejosdr/3918

Published: March 3, 2019

\begin{abstract}
This experimental study paper investigation mainly focused on CI engine performance with using the palm oil methyl ester (POME). The injection timing (IT) varied from $19^{\circ} \mathrm{btdc}, 23^{\circ} \mathrm{btdc}, 27^{\circ} \mathrm{btdc}$ and $31^{\circ} \mathrm{btdc}$ with increment step of $4^{\circ} \mathrm{CA}$ and similarly, injection opening pressure were varied from $210 \mathrm{bar}, 220 \mathrm{bar}$, $230 \mathrm{bar}, 240 \mathrm{bar}$ and $250 \mathrm{bar}$ with increment order of $10 \mathrm{bar}$ in the existed diesel engine. The final results were reported for optimized parameters of diesel engine with engine speed $1500 \mathrm{rpm}$ and CR 17.5. The experimental results of diesel engine performance improved in terms of brake thermal efficiency (BTE) and substantial reduction of harmful emissions at both optimized engine parameters of $27^{\circ} \mathrm{BTDC}$ and $240 \mathrm{bar}$, when engine has powered with Palm oil methyl ester (POME) as a alternative fuel.
\end{abstract}

Keywords: palm oil methyl ester (POME), injection strategies, emission characteristics

\section{INTRODUCTION}

The many researchers have worked on the biodiesel fuels in diesel engine and they were reported that, there were many methods and several research works has been carried out on conventional diesel engine (Murugesan et al., 2009; Atadashi et al., 2010; Banapurmath et al., 2009). The decaying fossil fuels are not meeting all the standards of euro norms in diesel engine throughout the world wide. The engine is emitting very harmful pollutants to the environment. The exhausted these harmful pollutants affect on the human health and living beings. Hence the stringent decision has taken towards usage of alternative fuels in diesel engine (Naik et al., 2010). The application of diesel engine is more due to higher efficiency and more power output. But in contrast, the diesel engine has emitted the more harmful pollutants like NOx, CO, HC etc. The consideration of all the emission issues of diesel engine tends to control emissions by external agencies. The external agencies are framed the emissions norms to reduce the emissions from diesel engine (Mani et al., 2011). Now days pollution increases day by day, hence research activities has taken very hard decision to control the pollutants from diesel engine. Hence, research works were carried with different varieties fuel combination along with injection parameters (Atmanli et al., 2014; Gautam and Agarwal, 2013). Transesterification process is most common method to reduce the viscosity of biodiesel. The transesterified biodiesel fuel is one suitable for I.C engine application to reduce the emission from engine. Hence many countries currently using the edible and non edible oils such as palm, soybean, cotton seed, Jatropha curcas, pongamia pinnata and linseed biodiesel fuels. The usage of these fuels in existed diesel engine ensured higher efficiency, by the comparison, efficiency of mineral diesel fuel showed higher efficiency as compared with biodiesel 
fuel when operated in diesel engine (Srivastava and Verma, 2008; Balat and Balat, 2008; Dixit and Rehman, 2012; Labeckas and Slavinskas, 2006; Kannan et al., 2012). The diesel engine operate with biodiesel has given the higher output along with reduced pollutants, that helps to reduce the environmental hazards such as green house effect, acid rain and smog problems. Hence with these benefits of biodiesel has taken stringent requirement and usage in diesel engine. The diesel engine has given higher thermal efficiency, minimum bSFC (brake specific fuel consumption), lowest $\mathrm{CO}$ and $\mathrm{HC}, 27.47 \%$ of smoke was reduced, when diesel operated with rice brain biodiesel with $2.5 \%$ of ethanol blends in biodiesel (Williams, 2013). The diesel engine has declined its BTE with increasing in the blend ratio in diesel fuel (DF) (Sharma and Murugan, 2013). The harmful pollutants like CO, smoke and HC were minimized by addition of Desulfurized tyre oils with DF, but DF showed minimum emissions than mixed oil. (Aydin and Ilkilic, 2015). The diesel engine showed the higher SFC and CO, $\mathrm{NOx}$ and $\mathrm{CO}_{2}$ emissions for blended plastic oil in DF (Pratoomyod and Laohalidanond, 2013). The experiments are carried on diesel engine powered with HKD15 $(20 \%$ Honne oil $+40 \%$ Kerosene $+25 \%$ Diesel $+15 \%$ Dimethyl carbonate $)$ gave higher engine output as compared with neat diesel. The emissions of engine like CO, HC and smoke density were decreased trend but slightly NOx level have increased (Venkanna and Reddy, 2011). Coconut oil biodiesel (COB), palm oil biodiesel (POB), and rubber seed oil biodiesel (ROB) were showed poor performance as compared to standard diesel fuel in CI engine (Satyanarayana and Muraleedharan, 2011). The 100\% biodiesel derived from rape seed oil gave engine output nearer to $12 \%$ lower and 20 to $25 \%$ SFC as compared to diesel engine (Aydin and Ilkilic, 2011). POME biodiesel operated in diesel engine gave, increased results in terms of SFC, BTE and NOx emissions and reduction in CO and smoke opacity emissions as compared to diesel fuel (Chattha et al., 2011). Chicha oil methyl ester (COME) used as alternate fuel in the diesel engine, showed reduction of CO \& HC emissions and increased in CO2 \& NOx emissions as compared to diesel (Tamilselvan and Nallusamy, 2017). Lower concentration of neem methyl ester (NOME) blend in diesel fuel gave better performance, combustion and emission characteristics in CI engine (Sivalakshmi and Balusamy, 2014). Power output of biodiesel fueled diesel engine was enhanced as increases in the blend of diesel fuel and reduced $\mathrm{CO} \& \mathrm{CO}_{2}$ emissions except $\mathrm{NOx}$ (Serin and Akar, 2014). 20\% blend of nut shell oil (CNSO) was showed better performance characteristics at all loads in diesel engine (Santhanakrishnan et al., 2017). M10B20 (10\% methanol + 90\% B20 POME blend] and M10B40 were showed better performance and emissions (except oxides of nitrogen) parameters in diesel engine as compared to mineral diesel fuel (Kumar and Kumar, 2015). Palm oil methyl ester [POME] biodiesel operate in diesel engine showed that, reduced BTE and emissions at 100\% load as compared to standard diesel fuel (Gad et al., 2017). Many research works has been carried out on diesel engine by using several biofuels with different injection strategies. The fuel injection and atomization processes are together changes the combustion as well as emission parameters in diesel engines. The engine better performance and reduced emission characteristics mainly depend upon the optimized droplet size, fuel injection and its penetration (Ramírez et al., 2012). The $\mathrm{NO}_{\mathrm{x}}$ emissions have been reduced in diesel engine by retarding the fuel IT, when engine operates with DF and BDF (Hountalas et al., 2001; Tao et al., 2005). The combustion parameters such as cylinder pressure and temperature were changed tremendously in diesel engine with effect of retarded fuel IT (Roy, 2009). The better BTE and reduced pollutants was observed in diesel engine with waste cooking oil as fuel at advanced $40^{\circ}$ BTDC fuel IT (Bari et al., 2004). The performance of CI engine has been improved by retarded IT effect with honge as a BDF used in engine (Banapurmath et al., 2008). The diesel engine performance has been improved by combined effect of IOP and retarded fuel IT, when cotton methyl ester as a BDF used in CI engine (Rosli et al., 2008; Banapurmath et al., 2012). The harmful products like CO, PM and HC were reduced in diesel engine by $14.2 \%, 13.26 \%$ and $9.3 \%$ respectively, when engine operated with JOME and pyrolysis blend at IT $24.5^{\circ} \mathrm{CA}$ BTDC (Sharma and Murugan, 2015). Similarly, the performance of engine has been improved in CI engine by increasing the IOP with varieties fuel combinations (Sukumar et al., 2009; Suresh et al., 2014). Ten holes nozzle geometry performed well in terms of better atomization and reduction of NOx emission in diesel engine at full load condition (Karra and Kong, 2010). By modification of combustion process, the oxides of nitrogen and CO emissions were highly reduced but increase in the BTE, unburnt HC and smoke level in biodiesel fueled diesel engine (Saravanan et al., 2014). Suggested that by varying number holes in nozzle injector reducing the oxides of nitrogen in biodiesel fueled diesel engine and minimize the unburnt HC, CO and BSFC (Subhash and Subramanian, 2014). At 240 bar injection pressure, there was enhanced in $\mathrm{BTE}$ and reduction of $\mathrm{bSFC}, \mathrm{CO}, \mathrm{CO}_{2}$, hydrocarbon, nitrogen oxides, and smoke intensity in diesel engine operated with Neem methyl ester (Balaji and Cheralathan, 2015). By varying theIT, injection pressure, CR and nozzle holes leads to enhanced the performance parameters like BTE, mean while reduced the emission characteristics in biodiesel fueled diesel engine but however oxides of nitrogen emission has been increases as number of holes increase in injector nozzle (Khandal et al., 2015). By adapting the advance IT and suitable combination of injector hole with combustion configuration can enhance the diesel engine performance, besides minimum harmful pollutants (Ranganatha et al., 2014). The diesel engine has improved in BTE $(28.8 \%)$ at 240 bar IOP mean while increased in the NOx emissions, when engine operated with blends of canola biodiesel Emulsion fuel (Anbarasu and Karthikeyan, 2015). The diesel engine powered with methyl ester of 
thevetia peruviana seed oil gave the higher BTE and reduced CO, HC and smoke emissions significantly at optimum injection parameters like $27^{\circ}$ BTDC and 225 bar IOP (Balusamy and Marappan, 2010). The diesel engine powered with different sources of biodiesel like cottonseed oil methyl ester (COME), honne oil methyl ester (HnOME) and honge oil methyl ester (HOME). The improved BTE and reduced HC, CO and smoke level emissions were observed in the diesel engine at optimized injection parameters such as $19^{\circ}$ BTDC, $230 \mathrm{bar}$ IOP and 4 holes of nozzle injector with $0.3 \mathrm{~mm}$ diameter (Wategave et al., 2014). The diesel engine powered with B40 blend biodiesel results in higher BTE than diesel with respect to combinations of CR 18, IOP 240 bar and advanced IT $26^{\circ}$ BTDC (Kumar et al., 2016). The diesel engine powered with hone oil methyl ester has given higher BTE is less than that of neat diesel fuel, mean while reduced emissions (smoke opacity (SO), $\mathrm{CO}, \mathrm{HC}$ and $\mathrm{NO}_{\mathrm{x}}$ ) was observed at advanced IT from 27 to 28 CA bTDC (Belagur and Chitimini, 2012). The diesel engine powered with blend of calophyllum inophyllum methyl ester has given higher thermal efficiency and SFC for 3 and 4 holes injectors at 250 bar IOP, at the same time substantial reduction of harmful pollutants levels for 5 holes nozzle operated 250 bar IOP (Vairamuthu et al., 2016). The drop size of biodiesel fuel can decreased on an average of 60 percentage, when 240 bar injection pressure maintained in the diesel engine operated BDF (Palani et al., 2015). The overall performance of diesel engine has been improved at optimized parameters such as retarded $19^{\circ}$ btdc, increased IOP of 230 bar and 4 holes nozzle injector, when engine powered with HOME as a BDF (Tumbal et al., 2016). The diesel engine powered with B20 blend of Mahua methyl ester has showed higher BTE and reduced emissions at injection pressure of 275 bar and IT of $21^{\circ}$ BTDC (Mohan et al., 2014).

From the above exhaustive literature survey came to know that, the injection pressure and ITs are varies in biodiesel operated diesel engine due to presence of higher viscosity, low vaporizing and spray characteristics of biodiesel fuels. The spray area increases with increase in the injection pressure of biodiesel fuels. The higher injection pressure and suitable IT leads to break the heavier droplet size of biodiesel fuels, since improve the spray atomization and air fuel mixing quality in the combustion chamber of engine. Hence, till day IT and injection pressure are not optimized properly for POME operated diesel engine. Hence it essential to change the injection strategies for improve the BTE of engine to operate the higher viscous biodiesel in CI engine. The emissions are also reduced in the engine at optimized injection parameters. The optimization of IT and injection pressure work scantily done with operated POME BDF in existed diesel engine. Hence in current study to improve the overall performance of POME fueled diesel engine by optimizing both IT and injection pressure.

\section{OBJECTIVES OF EXPERIMENTAL WORK}

a) To study POME properties and compared with standard mineral diesel fuel.

b) To conduct the experiments with various engine loads on POME operated diesel engine for various IT's 19, 23, 27 and $31^{\circ}$ BTDC.

c) To optimize the selected IT for higher efficiency and lower emissions.

d) To conduct the experiments with various engine loads with constant optimized IT on POME operated diesel engine for various IOP's 210 to 250 bar in step of 10 bars.

e) To optimize the selected IOP for higher efficiency and lower emissions.

\section{PRESENT WORK}

In present work is to optimize the injection timing and injection pressure for POME fuelled diesel engine. The optimized parameters leads to improve the overall efficiency of POME operated diesel engine with significant reduction of emissions.

\section{MATERIALS AND METHODS}

This section discusses the materials and methodology adopted in the experimental study.

\section{Fuel Properties in Current Experimental Study}

The fuel properties of POME are measured in the laboratory as shown in the below Table 1.

\section{Experimental Set-up and Methodology}

The Figure 2 shows the experimental rest rig set up with single cylinder, 4 stroke direct injection water cooled diesel engine. The details of specifications have been showed in the Table 2. The POME selected as a BDF in existed engine. In the first phase of study, various IT of $19^{\circ}, 23^{\circ}, 27^{\circ}$ and $31^{\circ} \mathrm{BTDC}$ were selected for engine operated with POME and diesel fuels. The engine operated at constant $1500 \mathrm{rpm}$ and CR 17.5. The 3 holes of 
Table 1. Properties of Diesel Palm oil and POME

\begin{tabular}{|c|c|c|c|c|}
\hline S1.No. & Properties & Diesel & PALM OIL & POME \\
\hline 1 & Density $\left(\mathrm{kg} / \mathrm{m}^{3}\right)$ & 840 & 890 & 880 \\
\hline 2 & Energy density (kJ/kg) & 43,000 & 36,400 & 38,400 \\
\hline 3 & Viscosity at $40^{\circ} \mathrm{C}(\mathrm{cSt})$ & $2-5$ & 43.28 & 3.94 \\
\hline 4 & Flash Point $\left({ }^{\circ} \mathrm{C}\right)$ & 75 & 280.5 & 160 \\
\hline 5 & Cetane Number & $45-55$ & - & 64.6 \\
\hline 6 & Carbon Residue (\%) & 0.1 & - & 76.5 \\
\hline 7 & Pour point $\left({ }^{\circ} \mathrm{C}\right)$ & -5 & - & 15 \\
\hline
\end{tabular}

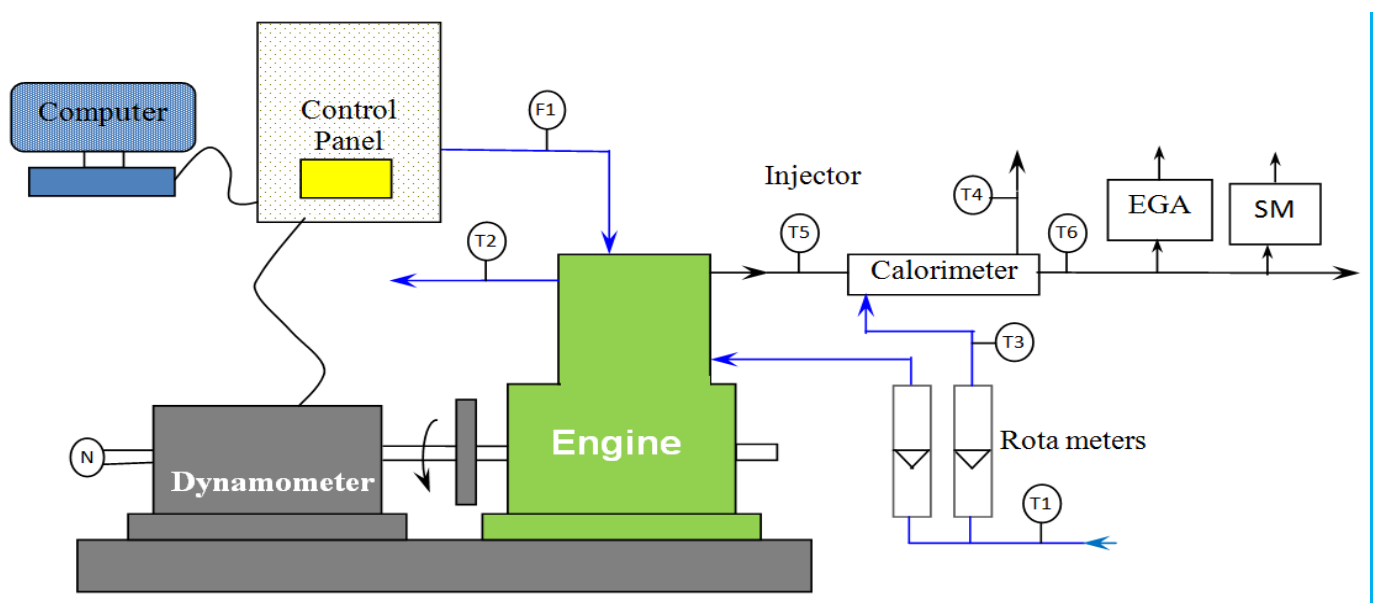

T1, T3 - Intake Water Temperature. T2 - Outlet Engine Jacket Water Temperature. T4 - Outlet Calorimeter Water Temperature, T5 - Exhaust Gas Temperature before Calorimeter, T6 -

\section{Exhaust Gas Temperature after Calorimeter, F1- Fuel Flow DP (Differential Pressure) unit. N - RPM encoder, EGA - Exhaust Gas Analyzer, SM - Smoke meter}

Figure 1. Experimental setup

nozzle with $0.3 \mathrm{~mm}$ orifice diameter selected for the experimentation in the existed engine. The 3 holes nozzle injector is existed in diesel engine as per the manufacturer recommendation. The experiments were carried for $80 \%$ and $100 \%$ of engine loads and readings were recorded at stable condition of engine. The optimized IT was found by conducting the experiments with various of engine loads in the POME fueled diesel engine. In the second phase of experimental study, the various IOP 200,210, 220, 230, 240 and 250 bar were selected for the experimental study. The optimized IOP was found by conducting the experiments at static optimized IT with various loads of engine, when operate with POME fueled diesel engine. The experimental work studied in terms of performance, combustion and emission characteristics for both optimized injection timing and injection pressure.

Finally engine tests were found to be higher efficiency and lower emissions at optimized parameters of engine. Engine cooling was achieved by supplying water through water jacket. A piezoelectric transducer (Make: PCB Piezotronics, Model: HSM 111A22, Resolution: $0.145 \mathrm{mV} / \mathrm{kPa}$ ) connected to the cylinder head was utilized to measure the in-cylinder gas pressure. Figure 2 shown used to measure smoke and emissions by Hartridge smoke meter and five-gas analyzers (A DELTA 1600 S-non-dispersive infrared analyzer) respectively under steady state condition of engine. The details of important specifications of exhaust analyzer and smoke meter are shown in Table 3.

\section{Analysis of Uncertainty}

The human error may be considered during measurement of engine parameters. The list of uncertainties is shown in the Table 3.

\section{RESULTS AND DISCUSSIONS}

\section{The Detailed of Experiments on Optimization of IT}

The engine runs with constant $1500 \mathrm{rpm}$ and CR 17.5. The experiments were conducted in engine at various injection timings such as $19^{\circ}, 23^{\circ}, 27^{\circ}$ and $31^{\circ}$ BTDC with manufactured recommended engine parameters of IOP 
Table 2. Specifications of the experimental test rig

\begin{tabular}{lll}
\hline SI No & Parameter & Specification \\
\hline 1 & Type & TV1 (Kirlosker make) \\
\hline 2 & Software used & Engine soft \\
\hline 3 & Nozzle opening pressure & 200-225 bar \\
\hline 4 & Governor type & Mechanical centrifugal type \\
\hline 5 & No of cylinders & Single cylinder \\
\hline 6 & No of strokes & Four stroke \\
\hline 7 & Fuel & H. S. Diesel \\
\hline 8 & Rated power & $5.2 \mathrm{~kW}(7 \mathrm{HP}$ at $1500 \mathrm{RPM})$ \\
\hline 9 & Cylinder diameter (Bore) & $0.0875 \mathrm{~m}$ \\
\hline 10 & Stroke length & $0.11 \mathrm{~m}$ \\
\hline 11 & Compression ratio & $17: 5: 1$ \\
\hline Air measurement manometer & \\
\hline 12 & Made & MX201 \\
\hline 13 & Type & U-Type \\
\hline 14 & Range & $100-0-100 \mathrm{~m}$ \\
\hline Eddy current dynamometer & \\
\hline 15 & Model & AG-10 \\
\hline 16 & Type & Eddy current \\
\hline 17 & Maximum & 7.5 (kW at $1500-3000$ RPM) \\
\hline 18 & Flow & Water must flow through Dynamometer during the use \\
\hline 19 & Dynamometer arm length & $0.180 \mathrm{~m}$ \\
\hline 20 & Fuel measuring unit-Range & $0-50 \mathrm{ml}$ \\
\hline
\end{tabular}
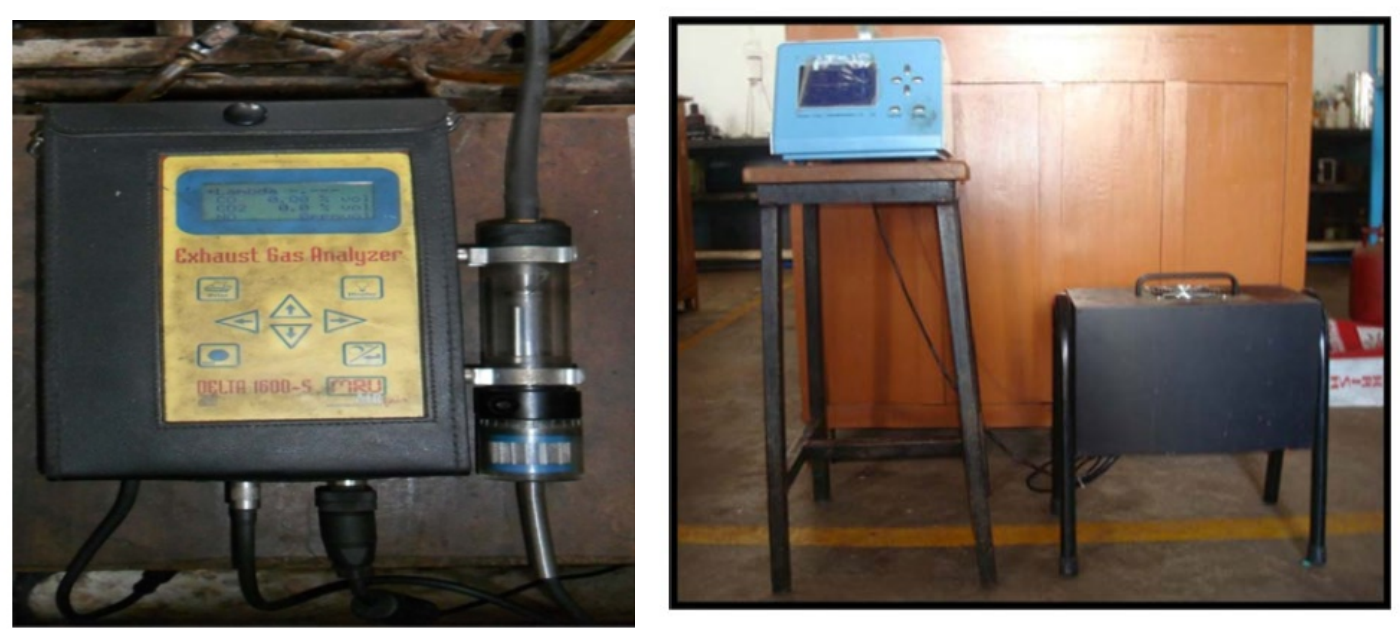

Figure 2. Exhaust Gas Analyzer and Smoke meter

205 bar, 3 holes nozzle injector with $0.3 \mathrm{~mm}$ diameter and HCC shape for POME. The engine experiments were carried for $0 \%, 20 \%, 40 \%, 60 \%, 80 \%$ and 100\% loads. The engine powered with both POME and mineral diesel fuels. The engine efficiency decreases by applying 100\% load due to negating effect. However, engine has given the optimum results at $80 \%$ load only. In view of optimization of injection timing, entire section discussions were enumerated in the below figures with respect to $80 \%$ load for both fuels. The diesel fuel experiments were recorded in engine as per manufacturer recommended standard conditions.

\section{IT Effect on BTE}

The variation of IT impact on BTE with BP as shown in Figure 3 for both POME and diesel fuels. The engine was showing the higher BTE (31.25\%) with neat diesel at $80 \%$ load as compared with POME due to variation of fuel properties such viscosity, density and calorific value. The engine powered with POME has given less BTE for all IT's due to higher viscosity leading poor mixing quality in the combustion chamber environment. However, improved BTE of POME operated engine was observed by advancing in fuel IT. The advanced fuel IT is prerequisite parameter for POME operated engine due to presence of heavier molecular structure of fuel. The engine performance can be improved by more time available in combustion phenomena of biodiesel. The obtained results with respect to BTE are $24.96,25.2,26.32$ and 25.75 for $19^{\circ}, 23^{\circ}, 27^{\circ}$ and $31^{\circ} \mathrm{BTDC}$ respectively, when engine powered with POME at $80 \%$ engine load condition. It was observed that, higher BTE (26.32\%) has obtained in engine with POME operation at $27^{\circ}$ BTDC, but BTE was decreased by advancing IT at $31^{\circ}$ BTDC due to negating effect of engine. 
Table 3. The specifications of exhaust gas analyzer and smoke meter

\begin{tabular}{|c|c|c|c|}
\hline Type & DELTA $1600 \mathrm{~S}$ & Type & HARTRIDGE SMOKEMETER-4 \\
\hline \multirow{2}{*}{ Object of Measurement } & \multirow{2}{*}{$\begin{array}{l}\text { Carbon monoxide (CO), Carbon Dioxide } \\
\left(\mathrm{CO}_{2}\right) \text { and Hydrocarbons }(\mathrm{HC})\end{array}$} & Object of Measurement & Smoke \\
\hline & & Measuring range opacity & $0-100 \%$ \\
\hline \multirow{4}{*}{ Range of Measurement } & \multirow{4}{*}{$\begin{array}{l}\mathrm{HC}=0 \text { to } 20,000 \mathrm{ppm} \text { as } \mathrm{C}_{3} \mathrm{H}_{8} \text { (Propane) } \\
\mathrm{CO}=0 \text { to } 10 \% \\
\mathrm{CO}_{2}=0 \text { to } 16 \% \\
\mathrm{O}_{2}=0 \text { to } 21 \% \\
\mathrm{NO}_{\mathrm{X}}=0 \text { to } 5000 \mathrm{ppm} \text { (as Nitric Oxide) }\end{array}$} & Accuracy & $\pm 2 \%$ relative \\
\hline & & Resolution & $0.1 \%$ \\
\hline & & Smoke length & $0.43 \mathrm{~m}$ \\
\hline & & Ambient Temperature & $-5^{0} \mathrm{C}$ to $+45^{0} \mathrm{C}$ \\
\hline \multirow{4}{*}{ Accuracy } & \multirow{4}{*}{$\begin{array}{l}\mathrm{HC}= \pm 30 \mathrm{ppm} \mathrm{HC} \\
\mathrm{CO}= \pm 0.2 \% \mathrm{CO} \\
\mathrm{CO}_{2}= \pm 1 \% \mathrm{CO}_{2} \\
\mathrm{O}_{2}= \pm 0.2 \% \mathrm{O}_{2} \\
\mathrm{NO}_{\mathrm{X}}= \pm 10 \mathrm{ppm} \mathrm{NO}\end{array}$} & Range & $-50 \mathrm{ClO}+43 \mathrm{C}$ \\
\hline & & Warm up time & $10 \mathrm{~min}$. (Self-controlled) at $20^{\circ} \mathrm{C}$ \\
\hline & & Speed of Response Time & Within 15 sec. for $90 \%$ response \\
\hline & & Sampling & Directly sampled from tail pipe \\
\hline \multirow{3}{*}{ Resolution } & \multirow{3}{*}{$\begin{array}{l}\mathrm{HC}=1 \mathrm{ppm} \\
\mathrm{CO}=0.01 \% \text { Vol. } \\
\mathrm{CO}_{2}=0.1 \% \text { Vol. } \\
\mathrm{O}_{2}=0.01 \% \mathrm{Vol} \\
\mathrm{NO}_{\mathrm{X}}=1 \mathrm{ppm}\end{array}$} & Power Supply & $\begin{array}{l}100 \text { to } 240 \text { V AC / 50HZ } \\
10-16 \text { V DC @15 amps } \\
\end{array}$ \\
\hline & & Size & $100 \mathrm{~mm} \times 210 \mathrm{~mm} \times 50 \mathrm{~mm}$. \\
\hline & & & \\
\hline Warm up time & $10 \mathrm{~min}$. (Self-controlled) at $20^{\circ} \mathrm{C}$ & & \\
\hline Speed of Response Time & Within 15 sec. for $90 \%$ response & & \\
\hline Sampling & Directly sampled from tail pipe & & \\
\hline Power Source & 100 to $240 \mathrm{~V} \mathrm{AC} / 50 \mathrm{~Hz}$ & & \\
\hline Weight & $800 \mathrm{~g}$ & & \\
\hline Size & $100 \mathrm{~mm} \times 210 \mathrm{~mm} \times 50 \mathrm{~mm}$ & & \\
\hline \multicolumn{4}{|c|}{ Table 4. The parameters of measurable variables and their accuracy } \\
\hline \multicolumn{2}{|l|}{ Measured variable } & \multicolumn{2}{|l|}{ Accuracy $( \pm)$} \\
\hline \multicolumn{2}{|l|}{ Load $(\mathrm{N})$} & \multicolumn{2}{|l|}{0.1} \\
\hline \multicolumn{2}{|l|}{ Engine speed (rpm) } & \multicolumn{2}{|c|}{1} \\
\hline \multicolumn{2}{|l|}{ Temperature $\left({ }^{\circ} \mathrm{C}\right)$} & \multicolumn{2}{|l|}{1} \\
\hline \multicolumn{2}{|l|}{ Fuel consumption $(\mathrm{g})$} & \multicolumn{2}{|l|}{0.1} \\
\hline \multicolumn{2}{|l|}{ Measured variable } & \multicolumn{2}{|l|}{ Uncertainty $( \pm)$} \\
\hline \multicolumn{2}{|l|}{$\overline{\mathrm{HC}}$} & \multicolumn{2}{|l|}{ \pm 1.2} \\
\hline \multicolumn{2}{|l|}{$\overline{\mathrm{CO}}$} & \multicolumn{2}{|l|}{ \pm 2.5} \\
\hline \multicolumn{2}{|l|}{$\overline{\mathrm{NOx}}$} & \multicolumn{2}{|l|}{ \pm 2.3} \\
\hline \multicolumn{2}{|l|}{ Smoke } & \multicolumn{2}{|l|}{ \pm 2.0} \\
\hline \multicolumn{2}{|l|}{ Calculated parameters } & Uncertainty $( \pm)$ & \\
\hline BTE (\%) & & \pm 1.2 & \\
\hline $\operatorname{HRR}\left(\mathrm{J} /{ }^{\circ} \mathrm{CA}\right)$ & & \pm 1.2 & \\
\hline
\end{tabular}

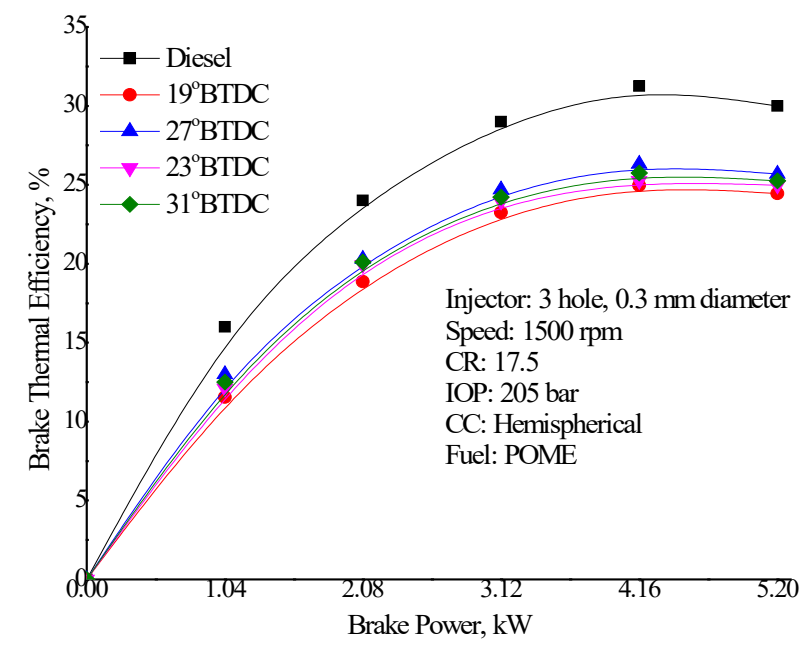

Figure 3. IT effect on BTE

\section{IT Effect on Smoke}

The variation of smoke level with BP for various IT's operated with diesel and POME fuels in engine as shown in below Figure 4. The diesel fuel has lower smoke level (46 HSU) at 80\% load as higher BTE due to lower viscosity, optimum evaporation of fuel and good spray characteristics of fuel. However, the neat diesel fuel showed 


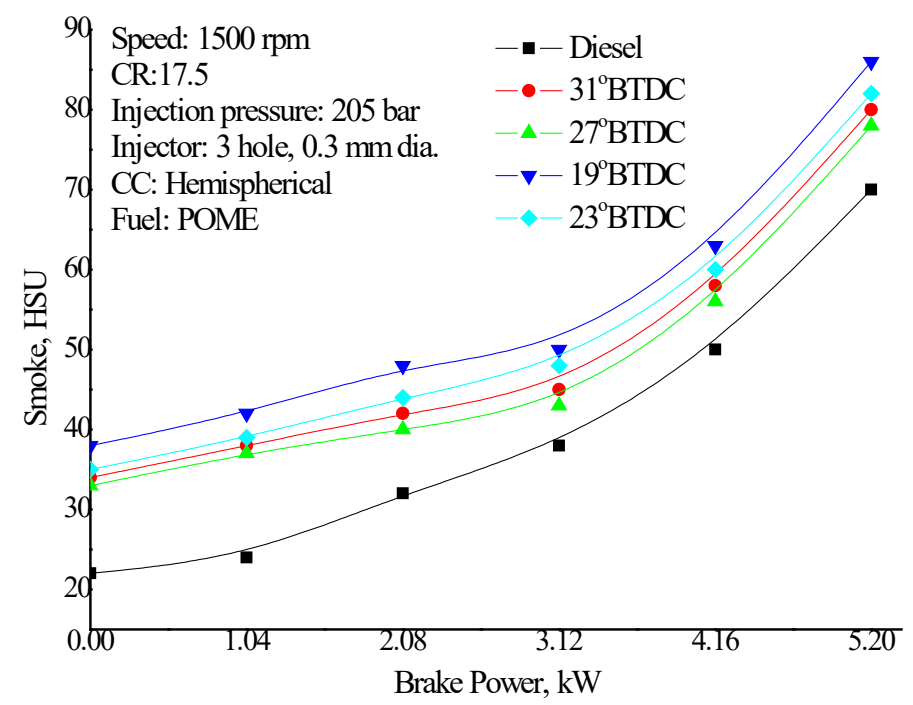

Figure 4. IT effect on Smoke opacity

minimum smoke level as compared to POME at all IT's. The smoke intensity related combustion phenomenon of fuel, since POME has heavier molecular structure and lower volatility characteristics leading to poor combustion process in the combustion environment. Hence POME exhibits higher smoke level for all operated IT's. However, the smoke intensity has been decreasing trend as fuel IT shifted from retarded to advance. This is due to fuel injection creates the minimum temperature and pressure with higher ID. The smoke level results of POME operated engine are $63,60,56$ and $58 \mathrm{HSU}$ for $19^{\circ}, 23^{\circ}, 27^{\circ}$ and $31^{\circ} \mathrm{BTDC}$ respectively at $80 \%$ engine load condition. The minimum smoke intensity was observed at $27^{\circ} \mathrm{BTDC}$ for POME powered engine but it still more than diesel fuel.

\section{IT Effect on Emissions of $H C$ and $C O$}

The variation of HC and CO emissions with BP for different IT's as shown in Figures 5 and 6 respectively for POME and diesel fuels. HC and CO are the most common emissions in the CI engine due to incomplete combustion. Hence lean mixture is formation in the combustion chamber during ID along with reduced velocity of non-uniformed fuel impinges from nozzle orifice. The minimum HC (36 ppm) and CO (0.1\%) emissions from diesel fueled engine at $80 \%$ load. However, the emissions were less than POME operated diesel engine. The higher emissions for POME all operated IT's in engine due to incomplete combustion and lower spray characteristics of fuel could be the reason. Hence with this evidence says that, the BTE of diesel operated engine than the POME operated engine. However, advanced fuel IT minimize the CO and HC emissions in POME operated engine at $80 \%$ load. This is due to the ignition delay enhances during combustion process of engine. The results of $\mathrm{HC}$ are $52 \mathrm{ppm}, 51 \mathrm{ppm}, 47 \mathrm{ppm}$ and $48 \mathrm{ppm}$ for $19^{\circ}, 23^{\circ}, 27^{\circ}$ and $31^{\circ}$ BTDC IT respectively for POME operated diesel engine at $80 \%$ of load. Similarly, the results of CO are $0.2,0.2,0.153$ and $0.18 \%$ for $19^{\circ}, 23^{\circ}, 27^{\circ}$ and $31^{\circ}$ BTDC IT respectively for POME powered diesel engine at $80 \%$ of load. But it was observed that, lowest $\mathrm{HC}$ and $\mathrm{CO}$ are formed at $27^{\circ}$ BTDC operating with POME.

\section{IT Effect on Emissions of $\mathrm{NO}_{\mathrm{x}}$}

Figure 7 explained that the effect of various IT's for NOx with BP as operated with POME and diesel fuels. The $\mathrm{NO}_{\mathrm{x}}$ emissions were drastically increases as increase in the load of engine for diesel and POME fuels. The cause of increased $\mathrm{NO}_{\mathrm{x}}$ emissions in both fuels is due to higher BTE leads to rise in the temperature by improved premixed combustion process in combustion chamber. However, diesel fuel operated engine was showed higher NOx level (1090 ppm) as compared to POME fuel operated with diesel engine at $80 \%$ load. The POME exhibits the lower $\mathrm{NO}_{\mathrm{x}}$ level in engine at retarded fuel IT, but by contract $\mathrm{NO}_{\mathrm{x}}$ level has been raised for advanced fuel IT. This is due to enhanced pre combustion process involved in the combustion environment. The results of POME operated diesel engine for $\mathrm{NO}_{\mathrm{x}}$ levels are 960, 1056, 1072 and $1068 \mathrm{ppm}$ for $19^{\circ}, 23^{\circ}, 27^{\circ}$ and $31^{\circ} \mathrm{BTDC}$ fuel IT respectively at $80 \%$ load. However, higher $\mathrm{NO}_{\mathrm{x}}$ level has been observed in POME operated diesel engine at $27^{\circ}$ BTDC. 


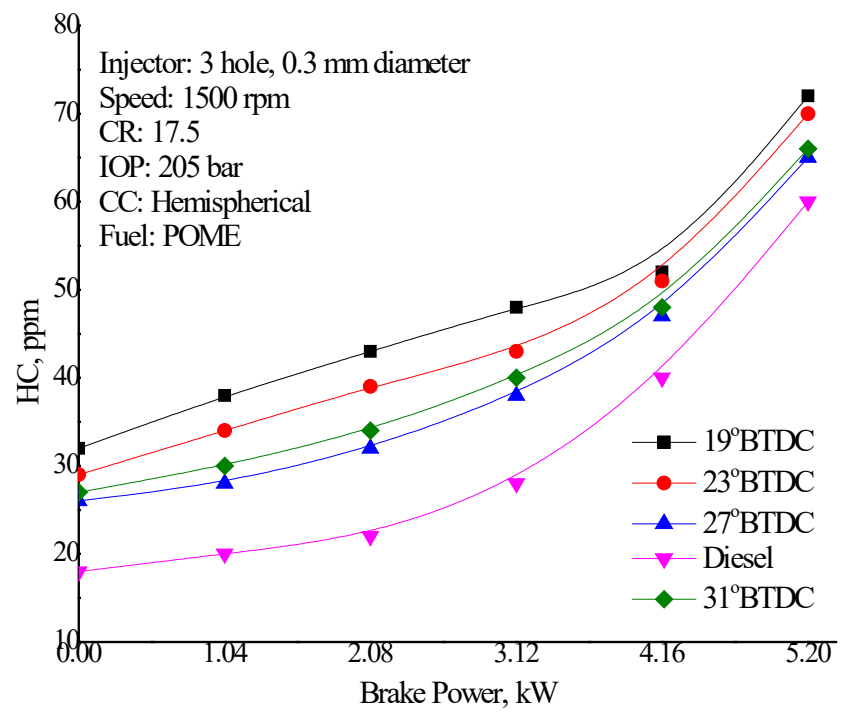

Figure 5. IT effect on Unburned Hydrocarbon Emissions

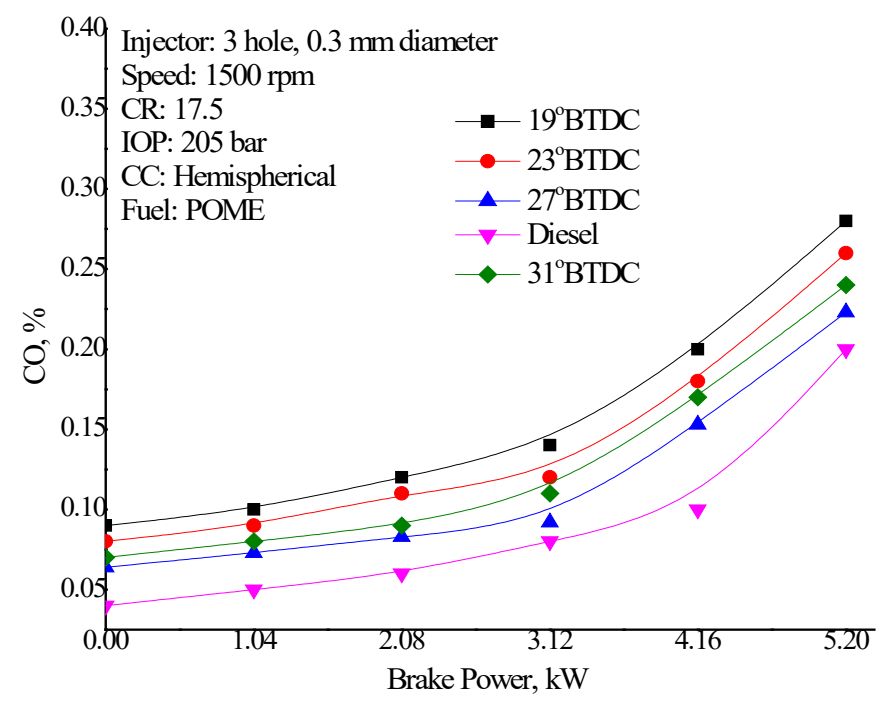

Figure 6. IT effect on Carbon Monoxide Emissions

\section{IT Effect on Peak Pressure}

Figure 8 showed that the variation of peak pressure with BP for various IT operates with diesel and POME fuels. Usually combustion process enhancing the peak pressure rise in the combustion chamber during the piston decent and formation with the useful work. The main cause of the pressure changes in the combustion chamber was due to auto ignition temperature of fuel. The diesel operated diesel fuel has higher PP (74 bar) than POME operated engine at 80\% load. POME was showed lower peak pressure for all fuel IT's due to lower energy content. The POME is leading to slow burning process due to longer ID and lower adiabatic flame temperature effect in the combustion chamber. From all above reasons of POME leads to incomplete combustion process. The PP was increased at advanced fuel IT, but PP was decreased at retarded fuel IT, this is due to effect ignition delay could be the reason. The results of PP with POME operated diesel engine are 68, 69, 70 and 69.5 bar for $19^{\circ}, 23^{\circ}, 27^{\circ}$ and $31^{\circ} \mathrm{BTDC}$ IT respectively at $80 \%$ load. However, PP was improved in the engine for $27^{\circ} \mathrm{BTDC}$ fuel IT as compared to other IT's. 


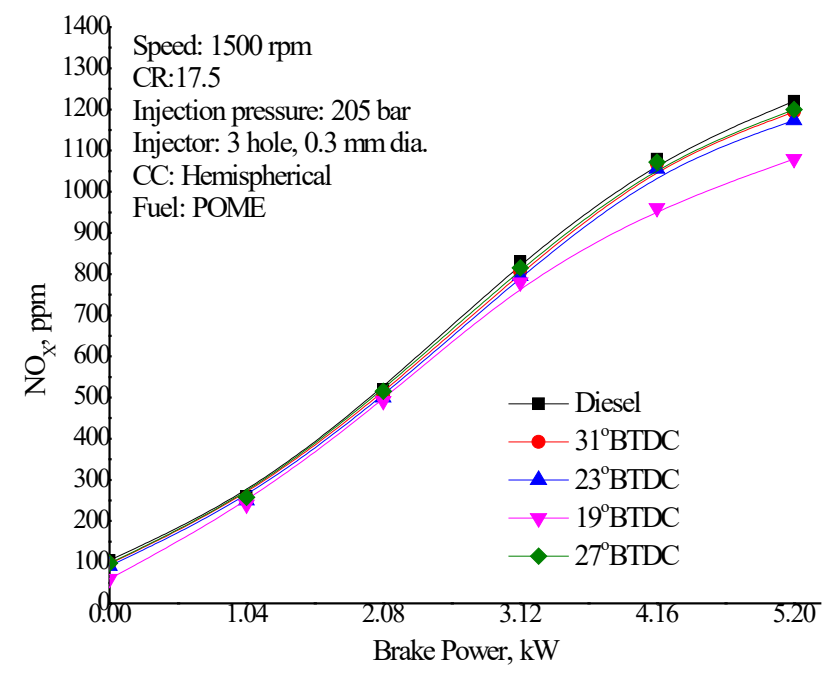

Figure 7. Injection timing effect on NOx Emissions

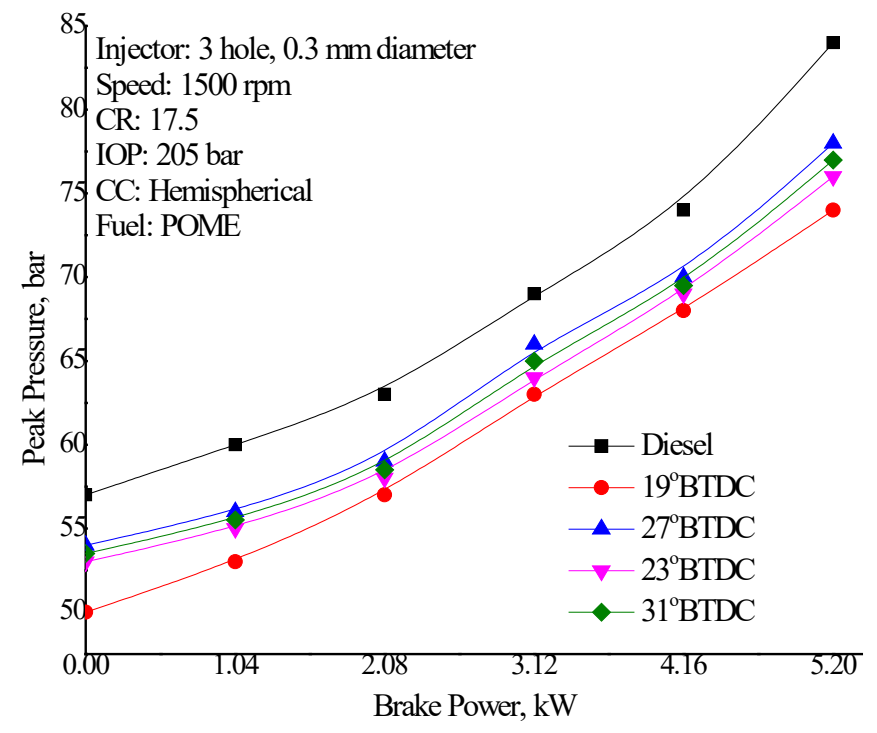

Figure 8. Injection timing effect on Peak Pressure

\section{IT Effect on Ignition Delay}

Figure 9 showed that the variation of the ignition delay with BP for all IT's operated with POME and diesel fuels. The neat diesel showed that lower ignition delay $\left(9.8^{\circ} \mathrm{CA}\right)$ as compared with POME with all IT at $80 \%$ load. The POME has lower ID due to its lower calorific value and higher viscosity. The ID was decreased at advanced IT due to higher thermal efficiency of engine, but ID was increased trend at retarded IT. Hence POME can improve the combustion process at advanced IT fuel in the engine. The ID results of POME operated engine are $10.5,10.3,10.2$ and $10.25^{\circ} \mathrm{CA}$ for $19^{\circ}, 23^{\circ}, 27^{\circ}$ and $31^{\circ} \mathrm{BTDC}$ IT respectively at $80 \%$ load. Finally, lower ID was obtained in the engine at $27^{\circ} \mathrm{BTDC}$ due to higher engine performance.

\section{IT Effect on Combustion Duration}

Figure 10 showed that the variation of CD with BP for all IT for POME and diesel fuels. The combustion duration calculated with respect to 90 percent cumulative heat release rate from start of combustion. The combustion duration was increased in both diesel and POME fuels as increasing in BP for all IT due to more fuel utilized for combustion process. However diesel has showed that lower $\mathrm{CD}\left(38^{\circ} \mathrm{CA}\right)$ as compared with POME at $80 \%$ load. The lower CD of POME due to longer diffusion combustion phase. The POME exhibits higher viscosity and improper fuel-air mixing characteristics in the cylinder that leads to incomplete combustion. The 


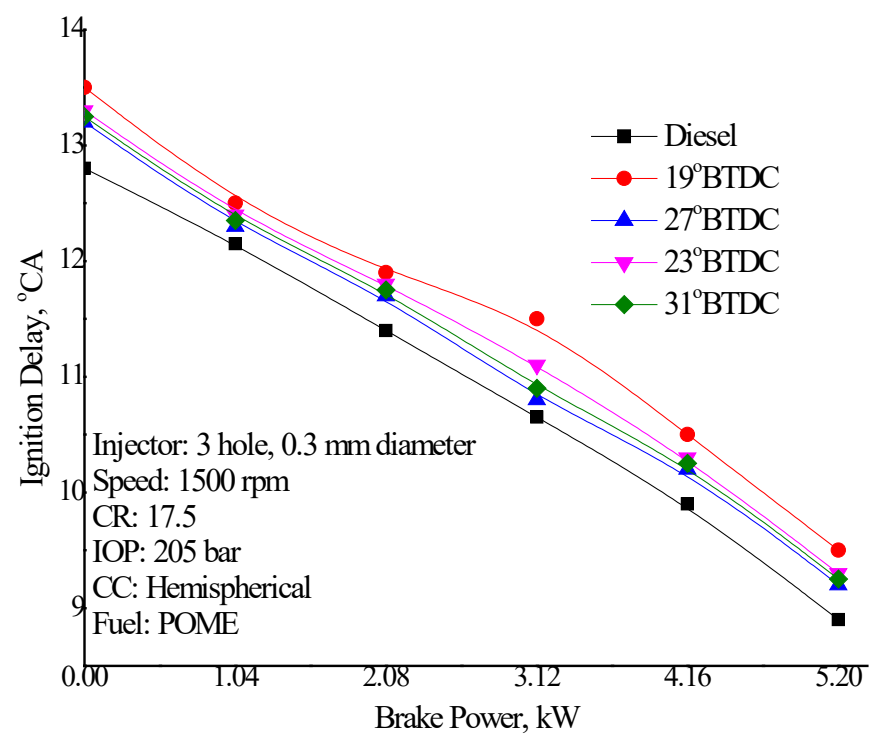

Figure 9. Injection timing effect on Ignition Delay Period

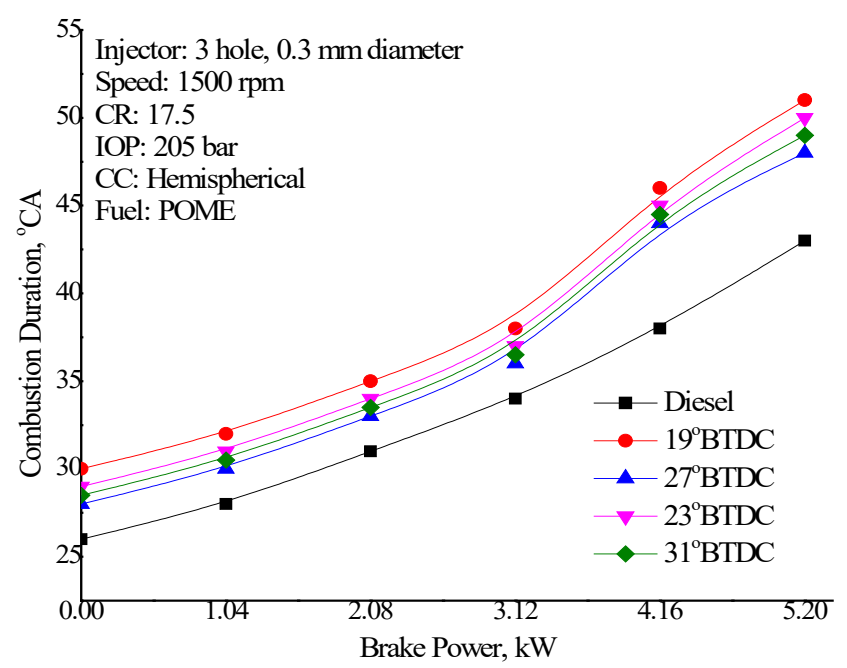

Figure 10. Injection timing effect on Combustion Duration

POME operated engine gave lower $\mathrm{CD}$ and higher $\mathrm{CD}$ for advanced and retarded IT's respectively. The recorded $\mathrm{CD}$ for POME operated engine are $46,45,44$ and $44.5^{\circ} \mathrm{CA}$ for $19^{\circ}, 23^{\circ}, 27^{\circ}$ and $31^{\circ} \mathrm{BTDC}$ IT respectively at $80 \%$ load. The lower CD was obtained in the engine at $27^{\circ}$ BTDC.

\section{IOP Effect on Optimized IT}

The Fuel IT $27^{\circ}$ BTDC has been optimized in the first phase of work at $80 \%$ of load in POME operated diesel engine. But by comparatively, diesel operated diesel engine showed the more efficient than POME operated engine due to variation in fuel properties. In second phase of work, the various IOP's such as 210, 220, 230, 240 and 250 bar are selected. The experiments are conducted in POME operated engine at $80 \%$ and $100 \%$ loads by keeping constant IT $27^{\circ}$ BTDC. The results of all POME operated engine IOP's are compared with diesel fuel operated engine at standard conditions. The selected IOP have been optimized in POME operated engine at $80 \%$ load for IT $27^{\circ}$ BTDC. The experimental results were discussed here only at $80 \%$ and $100 \%$ engine load condition.

\section{IOP Effect on BTE}

IOP effect on BTE with BP at 80\% and 100\% loads were showed in Figure 11 for diesel and POME fuels. The diesel fuel showed higher BTE than POME for all IOP in engine at 80\% load. The higher BTE in diesel fuel 


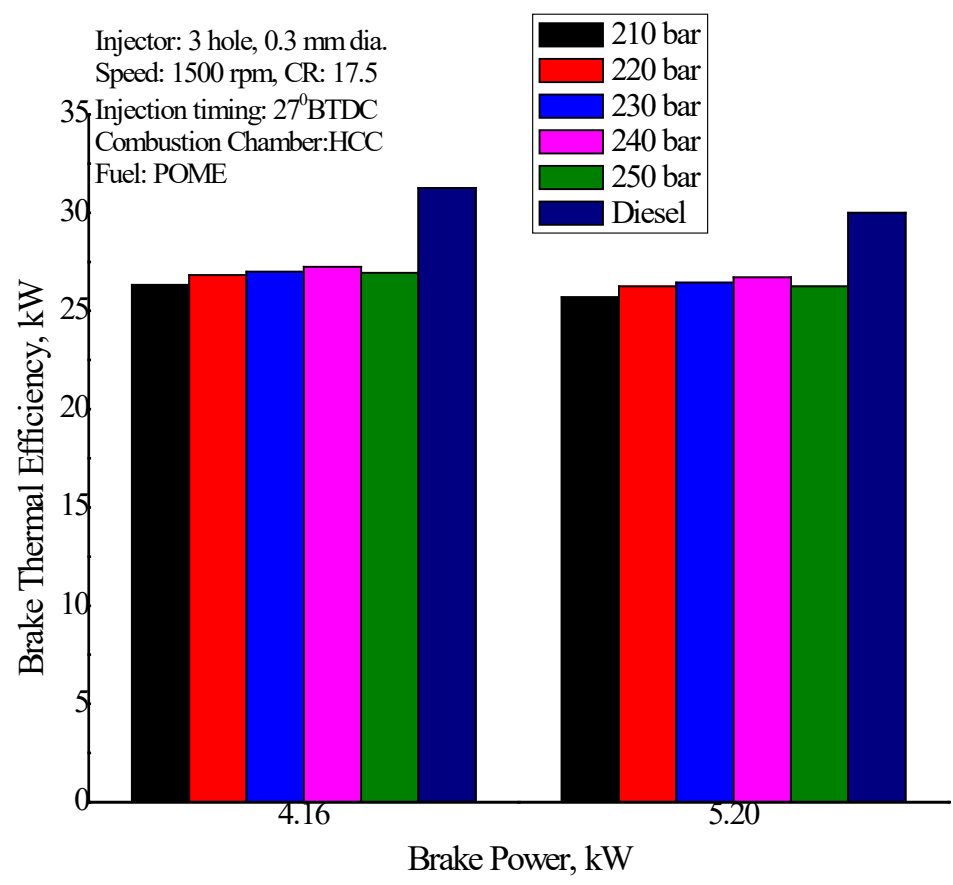

Figure 11. IOP effect on BTE

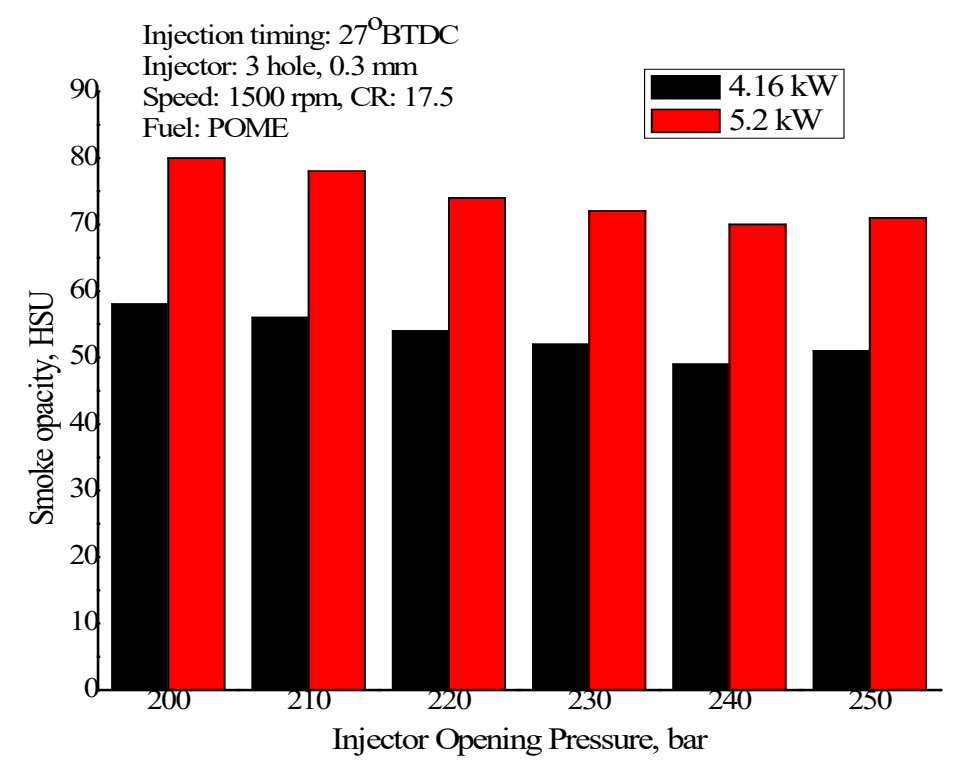

Figure 12. IOP effect on Smoke opacity

is due to higher energy content, optimum atomization and fuel spray characteristics of fuel. The BTE of POME operated engine has been improved as increase in IOP due to well atomization of fuel characteristics in the combustion chamber at advanced IT. The results of BTE with POME operated engine are 26.32, 26.82, 27, 27.25 and $26.94 \%$ for $210,220,230,240$ and 250 bar respectively for $80 \%$ load and $27^{\circ}$ BTDC. The BTE of POME operated engine gave higher BTE at 240 bar at $80 \%$ load, but at same time BTE has lowered at $100 \%$ load due to negation effect in the engine. Hence $80 \%$ load was optimized for engine.

\section{IOP Effect on Smoke Opacity}

From Figure 12 showed that variation of smoke level with BP for various IOP at $80 \%$ and $100 \%$ engine load with POME and diesel fuels. The fall of smoke level was observed as increasing in IOP for POME due to improved spray characteristics at $80 \%$ load condition. The smoke opacity was 49 HSU at 240 bar IOP but at 100\% load condition, smoke level was increase due to the reduced BTE for POME. However the smoke level was lesser for diesel than POME due to higher viscosity of POME. At $80 \%$ load condition and $27^{\circ} \mathrm{BTDC}$, the smoke level for POME were 58, 56, 54, 52, 49 and 51 HSU for 200, 210, 220, 230, 240 and 250 bar respectively. As per 


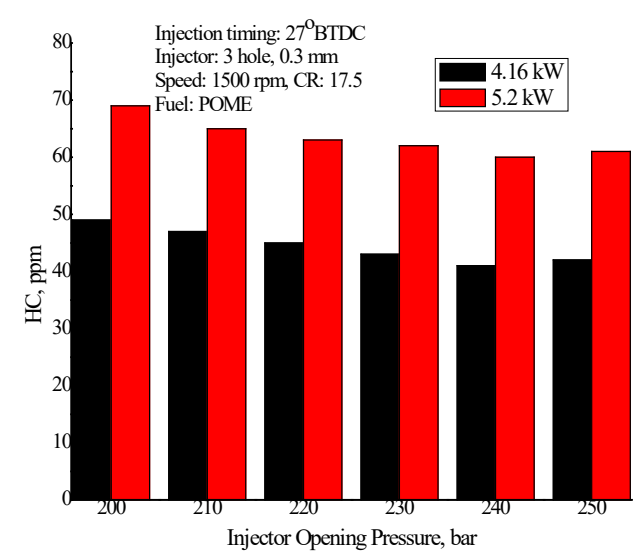

Figure 13. IOP effect on Unburned Hydrocarbon Emissions

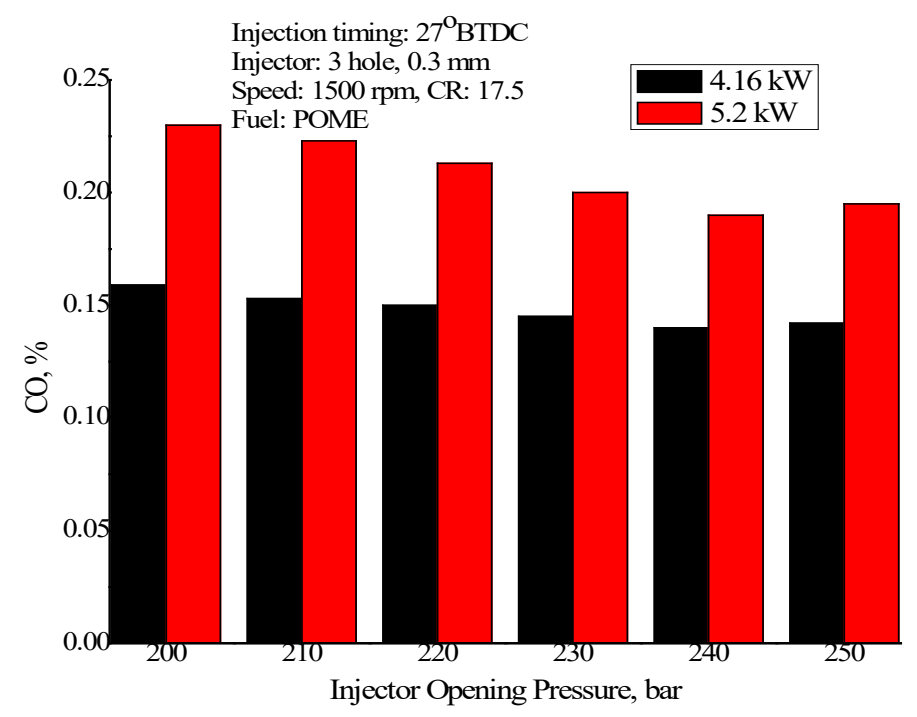

Figure 14. IOP effect on Carbon Monoxide Emissions

manufactured recommendation diesel fuel showed the smoke level was $46 \mathrm{HSU}$ at 205 bar and $23^{\circ}$ BTDC at $80 \%$ load.

\section{IOP Effect on $H C$ and CO Emissions}

Figures 13 and 14 showed that variation of emissions with BP for all IOP at $80 \%$ and $100 \%$ load with POME and diesel fuels. $\mathrm{HC}$ and $\mathrm{CO}$ emissions were decreases at part load but at same time emissions increases at higher loads in CI engine. The POME operated diesel engine showed higher emissions as compared with diesel engine. This is due to incomplete combustion of POME fuel in engine due to well atomized fuel spray characteristics. The emissions are controlled by higher injection pressure in the combustion environment. The HC and CO emissions were decreased for POME operation at higher IOP with advanced IT. The POME operated engine showing the results of HC emissions are 49, 47,45,43,41 and $42 \mathrm{ppm}$ for 200, 210, 220, 230, 240 and 250 bar respectively at $80 \%$ load and $27^{\circ}$ BTDC. Similarly, for CO are $0.159,0.153,0.15,0.145,0.14$ and $0.142 \%$ for 200, 210, 220, 230, 240 and 250 bar respectively at $80 \%$ load and $27^{\circ}$ BTDC. From the results the lower emissions were observed at 240 bar IOP for POME fueled diesel engine.

\section{IOP Effect on NOx Emission}

The figure 15 depicts that the variation of $\mathrm{NO}_{\mathrm{x}}$ emission with BP for all IOP's at $80 \%$ and $100 \%$ engine loading condition with POME and diesel fuel. High impact pressure of nozzle changes the combustion process in combustion chamber leads to raise the $\mathrm{NO}_{\mathrm{x}}$ level for tested fuel. This is due to the improved mixing of air and fuel characteristics leads to temperature rise in the combustion chamber. Hence, $\mathrm{NO}_{\mathrm{x}}$ level was enhanced as increase the injection pressure for POME. But diesel was showed higher NOx level as compared to POME due to attainment peak temperature in the cylinder. The results of $\mathrm{No}_{\mathrm{x}}$ levels with POME operated engine are 1045, 1060, 1066, 1072, 1080 and $1076 \mathrm{ppm}$ for 200, 210, 220, 230, 240 and 250 bar respectively at $80 \%$ load and $27^{\circ}$ 


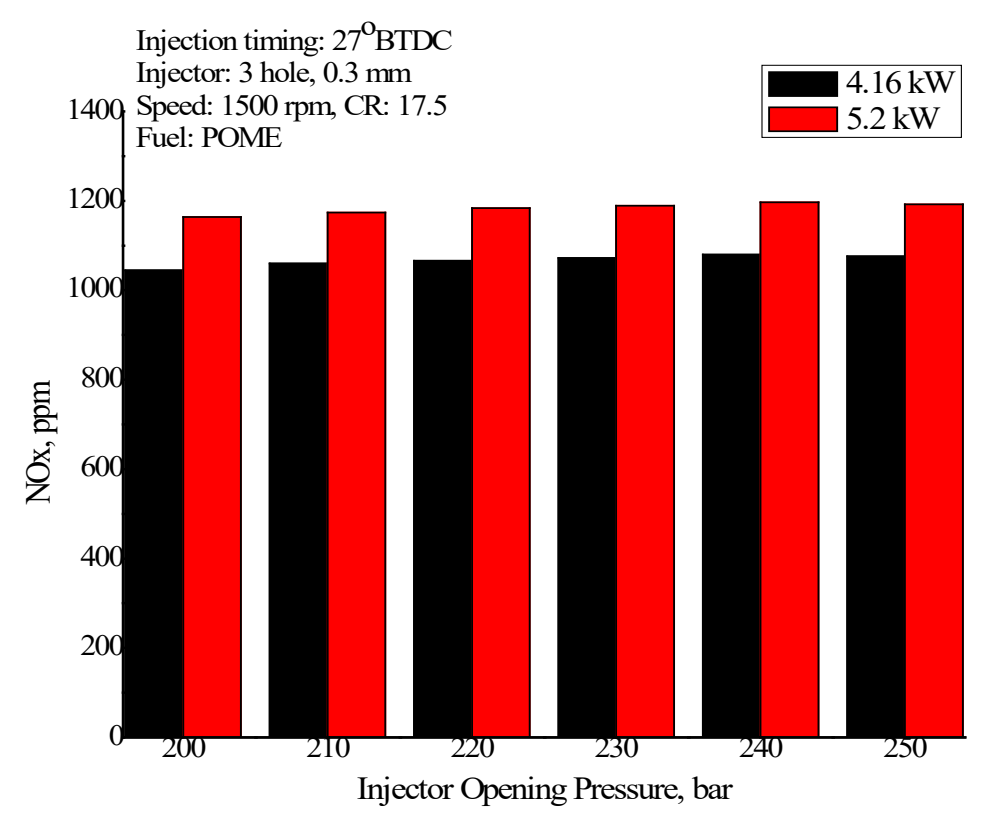

Figure 15. IOP effect on $\mathrm{NO}_{\mathrm{x}}$ Emissions

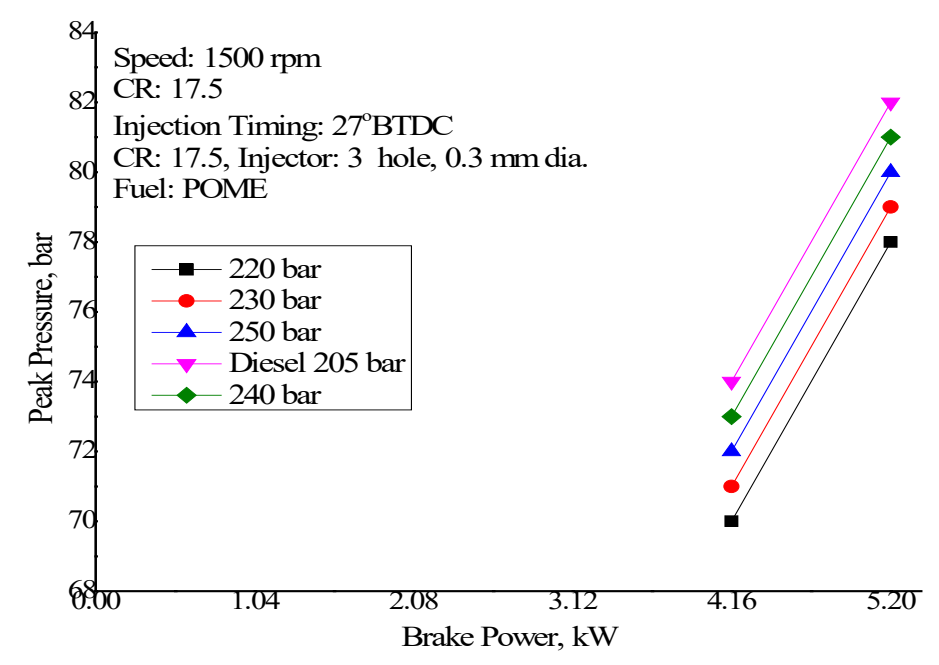

Figure 16. Effect of injector opening pressure on Peak Pressure

BTDC. The higher $\mathrm{NO}_{\mathrm{x}}$ level has been observed for POME operated engine at 240 bar and $27^{\circ}$ BTDC due to higher BTE of the engine.

\section{IOP Effect on Peak Pressure}

Figure 16 showed that the variation of peak pressures with BP for all IOP at $80 \%$ and $100 \%$ load with POME and diesel fuels. The lower peak pressure observed for the POME operation as compared with diesel. This is due to lower energy content and lower BTE of POME. The peak pressure of POME operated engine was enhanced for increasing in IOP due to lower combustion diffusion phase. The higher peak pressure was observed at 240 bar of IOP as compared to remaining IOP's but further decrease trend of peak pressure showed due to negation effect. The observed readings for POME operated engine are 71, 72, 74 and 73 bar for 220, 230, 240 and 250 bar respectively at $80 \%$ load condition and $27^{\circ}$ BTDC.

\section{IOP effect on Ignition Delay Period}

Figure 17 explained that variation of ID with BP for various IOP's with POME and diesel fuels at $80 \%$ and $100 \%$ load. ID calculated with respect to static injection period, but ID was decreased trend for POME operation with increased IOP. However higher ID for POME was observed compared to diesel due to the higher viscosity. But ID has been reduced at 240 bar for POME operated engine that leads to improved combustion process in the 


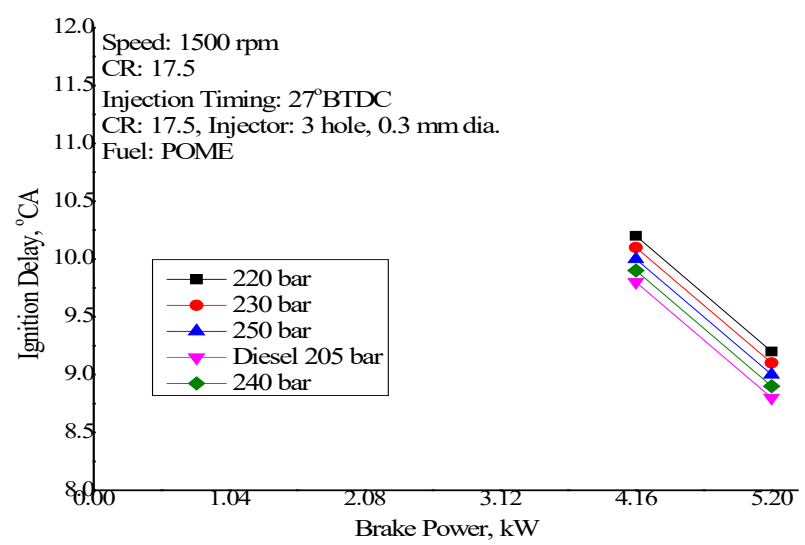

Figure 17. Injector opening pressure effect on Ignition Delay Period

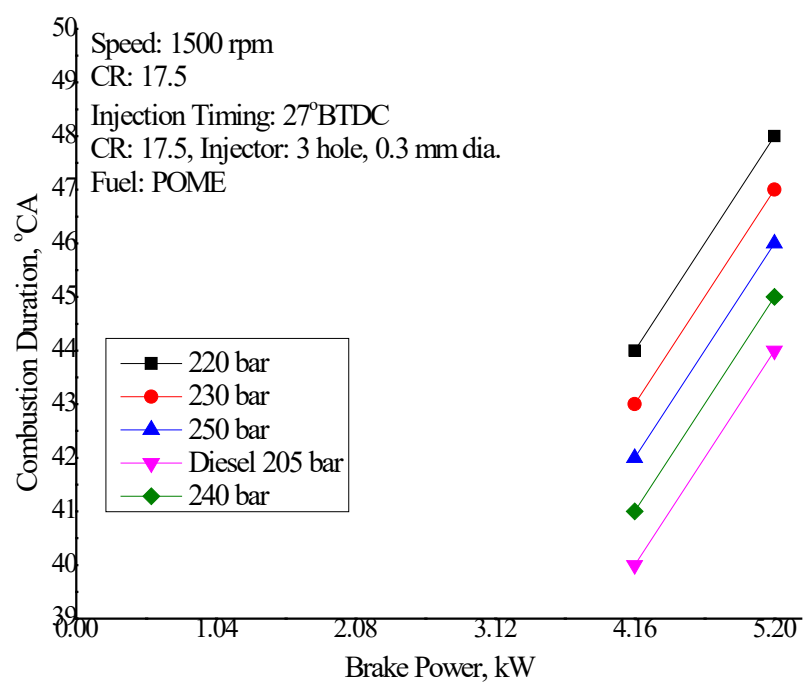

Figure 18. Injector opening pressure effect on Combustion Duration

cylinder. The readings obtained for POME operated engine are 10.1, 10, 9.8 and $9.9^{\circ} \mathrm{CA}$ for 220, 230, 240 and 250 bar respectively at $80 \%$ load and $27^{\circ}$ BTDC.

\section{IOP effect on Combustion Duration}

From Figure 18 we observed that the variation of CD with BP for various IOP's with POME and diesel fuels at $80 \%$ and $100 \%$ load. The CD calculation based on the $90 \%$ cumulative heat release rate from the starting point of combustion. The $\mathrm{CD}$ was high at higher output of the engine for both fuels due to increased fuel quantity in combustion chamber. However, higher CD for POME compared with diesel fuel due to lengthier combustion diffusion stage. POME has higher viscosity to increased $C D$ might be the reason. Hence POME operated engine was showing incomplete combustion in the cylinder leads to increased CD at low IOP. As increased in IOP the CD was decreased due to well atomization of POME. The lower CD was observed at 240 bar. The results of CD with POME operated engine are 43, 42, 40 and $41^{\circ} \mathrm{CA}$ for 220, 230, 240 and 250 bar respectively at $80 \%$ load and $27^{\circ}$ BTDC.

\section{CONCLUSIONS}

From the exhaustive experimental tests conducted with POME and diesel operation in CI engine, the following conclusions were made at $80 \%$ load.

- In first phase of work, POME operated diesel engine gave higher BTE and reduced CO, HC, smoke emissions except $\mathrm{NO}_{\mathrm{x}}$ level at $27^{\circ} \mathrm{BTDC}$ fuel IT. 
- In second phase of work, POME operated diesel engine gave higher BTE and reduced emissions CO, $\mathrm{HC}$, smoke emissions except $\mathrm{NO}_{\mathrm{x}}$ level at $27^{\circ} \mathrm{BTDC}$ fuel IT and $240 \mathrm{bar}$ IOP.

- In the view of comparison between first phase and second phase works, the BTE of engine improved 3\%, $\mathrm{CO}$ decreased $8 \%, \mathrm{HC}$ and smoke are decreased $12 \%$ and $\mathrm{NO}_{\mathrm{x}}$ increased $0.7 \%$ as compared to first phase work.

- The POME operated diesel engine showed lower performance as compared with diesel operated diesel engine.

On overall experimental works depicted that, the combined effect of $27^{\circ}$ BTDC and 240 bar IOP of engine enhanced the BTE and reduced pollution, when POME as fuel used in the CI engine. Hence POME fuel can be used as an alternative fuel in diesel engine to save huge amount of the fossil fuel requirement in our country and worldwide.

\section{REFERENCES}

Anbarasu, A. and Karthikeyan, A. (2015). Effect of injection pressure on the performance and emission characteristics of CI engine using canola emulsion fuel. International Journal of Ambient Energy, https://doi.org/10.1080/01430750.2015.1092472

Atadashi, I. M., Aroua, M. K. and Abdul Aziz, A. (2010). High quality biodiesel and its diesel engine application: A review. Journal of Renewable and Sustainable Energy Reviens, 14(7), 1999-2008. https://doi.org/10.1016/j.rser.2010.03.020

Atmanli, A., Ileri, E. and Yuksel, B. (2014). Experimental investigation of engine performance and exhaust emissions of a diesel engine fueled with diesel-n-butanol vegetable oil blends. Energy Convers Manage, 81, 312 21. https:// doi.org/10.1016/j.enconman.2014.02.049

Aydın, H. and Ilk1lıc, C. (2015). Analysis of combustion, performance and emission characteristics of a diesel engine using low sulfur tire fuel. Fuel, 143, 373-82. https://doi.org/10.1016/j.fuel.2014.11.075

Aydin, H. and Ilkilic, C. (2011). Exhaust emissions of a CI engine operated with biodiesel from rapeseed oil. Energy Sources, Part A: Recovery, Utilization, and Environmental Effects, 33(16), 1523-1531. https:// doi.org/10.1080/15567030903397982

Balaji, G. and Cheralathan, M. (2015): Experimental investigation of varying the fuel injection pressure in a direct injection diesel engine fueled with methyl ester of neem oil. International Journal of Ambient Energy. https:// doi.org/10.1080/01430750.2015.1111846

Balat, M. and Balat, H. (2008). A critical review of bio-diesel as a vehicular fuel. Energy Convers Manage, 49, $2727-$ 41. https://doi.org/10.1016/j.enconman.2008.03.016

Balusamy and Marappan, R. (2010). Effect of Injection Time and Injection Pressure on CI Engine Fuelled with Methyl Ester of Thevetia Peruviana Seed Oil. International Journal of Green Energy, 7(4), 397-409. https://doi.org/10.1080/15435075.2010.493811

Banapurmath, N. R., Hosmath, R. S. and Tewari, P. G. (2008). Performance and Emissions Characteristics of a DI Compression Ignition Engine Operated OnHonge, Jatropha and Sesame Oil Methyl Esters. Renewable Energy, 33, 1982-1988. https://doi.org/10.1016/j.renene.2007.11.012

Banapurmath, N. R., Tewari, P. G. and Vinodkumar, V. (2009). Combustion and emission characteristics of a direct injection CI engine when operated on Marotti oil methyl ester and blends of Marotti oil methyl ester and diesel. International Journal of Sustainable Engineering, 2, 192-200. https://doi.org/10.1080/19397030903089983

Banapurmath, N. R., Tewari, P. G. and Gaitonde, V. N. (2012). Experimental investigations on performance and emission characteristics of Honge oil biodiesel (HOME) operated compression ignition engine. Renewable Energy, 48, 193-201. https:/ /doi.org/10.1016/j.renene.2012.04.010

Bari, S., Yu, C. W. and Lim, T. H. (2004). Effect of fuel injection timing with waste cooking oil as a fuel in direct injection diesel engine. Proc. Instn. Mech. Engrs. IMechE, Part D, Journal of Automobile Engineering, 218, 93-104. https://doi.org/10.1243/095440704322829209

Belagur, V. K. and Chitimini, V. R. (2012). Influence of static injection timing on combustion, emission and performance characteristics of DI diesel engine fuelled with honne oil methyl ester. International Journal of Ambient Energy, 33(2), 65-74. https:// doi.org/10.1080/01430750.2011.636209

Chattha, J. A., Bannikov, M. G. and S. Iqbal. (2011). The performance and emissions of a direct injection diesel engine fueled with pongamia pinnata methyl esters. Energy Sources, Part A: Recovery, Utilization, and Environmental Effects, 33(9), 890-897. https:// doi.org/10.1080/15567030903330777

Dixit, S. and Rehman, A. (2012). Linseed oil as a potential resource for bio-diesel: a review. Renew Sustain Energy Rev, 16, 4415-21. https:/ / doi.org/10.1016/j.rser.2012.04.042 
Gad, M. S., El-Araby, R., Abed, K. A., El-Ibiari, N. N., El Morsi, A. K. and El-Diwani, G. I. (2017). Performance and emissions characteristics of C.I. engine fueled with palm oil/palm oil methyl ester blended with diesel fuel. Egyptian Journal of Petroleum.

Gautam, A. and Agarwal A. K. (2013). Experimental investigations of comparative performance, emission and combustion characteristics of a cotton seed biodiesel-fueled four-stroke locomotive diesel engine. Int J Engine Res, 14(4), 354-72. https://doi.org/10.1177/1468087412458215

Hountalas, D. T., Kouremenos, D. A., Binder, K. B., Raab, A. and Schnabel, M. H. (2001). Using advanced Injection timing and EGR to Improve DI engine efficiency at Acceptable NO and Soot levels. Society of Automotive Engineers, Paper No: 2001-01-0199.

Kannan, D., Pachamuthu, S., Nurun, N. M., Hustad, J. E. and Lovas, T. (2012). Theoretical and experimental investigation of diesel engine performance, combustion and emissions analysis fueled with the blends of ethanol, diesel and Jatropha methyl ester. Energy Convers Manage, 53, 322-31. https://doi.org/10.1016/j.enconman.2011.09.010

Karra, P. K. and Kong, S. C. (2010). Experimental study on effects of nozzle holes geometry on achieving low diesel engine emissions. Journal of Engineering for Gas Turbines and Power, 132(2), 022802. https://doi.org/10.1115/1.3124791

Khandal, S. V., Banapurmath, N. R., Gaitonde, V. N. and Hosmath, R. S. (2015). Effect of Number of Injector Nozzle Holes on the Performance, Emission and Combustion Characteristics of Honge Oil Biodiesel (HOME) Operated DI Compression Ignition Engine. Journal of Petroleum \& Environmental Engineering.

Kumar, S. R. and Kumar, K. S. (2015). Effect of methanol blending with Pongamia pinnata biodiesel and diesel blends on engine performance and exhaust emission characteristics of an unmodified compression ignition engine. International Journal of Ambient Energy, 36(2), 70-75.

Kumar, N., Varun and Chauhan, S. R. (2016). Evaluation of the effects of engine parameters on performance and emissions of diesel engine operating with biodiesel blend. International Journal of Ambient Energy, 37(2), 121-135. https://doi.org/10.1080/01430750.2014.907208

Labeckas, G. and Slavinskas, S. (2006). The effect of rapeseed oil methyl ester on direct injection diesel engine performance and exhaust emissions. Energy Convers Manage, 47, 1954-67. https://doi.org/10.1016/j.enconman.2005.09.003

Mani, M., Nagarajan, G. and Sampath, S. (2011). Characterization and effect of using waste plastic oil and diesel fuel blends in compression ignition engine. Energy, 36, 212-219. https://doi.org/10.1016/j.energy.2010.10.049

Mohan, B., Yang, W., Raman, V., Sivasankaralingam, V. and Chou, S. K. (2014), Optimization of biodiesel fueled engine to meet emission standards through varying nozzle opening pressure and static injection timing. Applied Energy, 130, 450-457. https://doi.org/10.1016/j.apenergy.2014.02.033

Murugesan, A. Umarani, C., Subramanian, R. and Nedunchezhian, N. (2009). Bio-diesel as an alternative fuel for diesel engines-A Review. Renewable and Sustainable Energy Reviews, 13(3), 653-662. https://doi.org/10.1016/j.rser.2007.10.007

Naik, S. N., Vaibhav, V., Goud Prashant, K., Rout, A. and Dalai, K. (2010). Production of first and second generation biofuels: A comprehensive review. Renewable and sustainable energy reviews, 14, 578-597. https://doi.org/10.1016/j.rser.2009.10.003

Palani, R., Nallusamy, N. and Pitchandi, K. (2015). Spray characteristics of diesel and derivatives in direct injection diesel engines with varying injection pressures. Journal of Mechanical Science and Technology, 29(10), 4465-4471. https://doi.org/10.1007/s12206-015-0945-9

Pratoomyod, J. and Laohalidanond, K. (2013). Performance and Emission Evaluation of Blends of Diesel fuel with Waste Plastic Oil in a Diesel Engine. IJESIT, 2(2).

Ramírez, A. I., Som, S., Rutter, T. P., Longman, D. E. and Aggarwal, S. K. (2012). Investigation of the Effects of Rate of Injection on Combustion Phasing and Emission Characteristics: Experimental and Numerical Study. Spring Technical Meeting of the Central States Section of the Combustion Institute.

Ranganatha, S. L., Chandrashekar, T. K., Banapurmath, N. R. and Nashipudi, P. (2014). Effect of Injection Timing, Combustion Chamber Shapes and Nozzle Geometry on the Diesel Engine Performa. Universal Journal of Petroleum Sciences, 2, 74-95.

Rosli, A. B., Semin, A. and Rahim, I. (2008). Fuel injection pressure effect on performance of direct injection diesel engines based on experiment. American Journal of Applied Sciences, 5, 197-202. https://doi.org/10.3844/ajassp.2008.197.202

Roy, M. M. (2009). Effect of fuel injection timing and injection pressure on combustion and odorous emissions in DI diesel engine. Journal of Energy Resources Technology, ASME Transactions, 131, 1-8. https://doi.org/10.1115/1.3185346 
Santhanakrishnan, S., Kumar, B. and Ramani, M. (2017). Evaluation of diesel engine performance using dieselcashew nut shell oil blends. International Journal of Ambient Energy, 38(1), 104-107. https://doi.org/10.1080/01430750.2015.1048898

Saravanan, S., Nagarajan, G. and Sampath, S. (2014). Combined effect of injection timing, EGR and injection pressure in reducing the $\mathrm{NO}_{\mathrm{x}}$ emission of a biodiesel blend. International Journal of Sustainable Energy, 33(2), 386399. https:// doi.org/10.1080/14786451.2012.743464

Satyanarayana, M. and Muraleedharan, C. (2011). Investigations on performance and emission characteristics of vegetable oil biodiesels as fuels in a single cylinder direct injection diesel engine. Energy Sources, Part A: Recovery, Utilization, and Environmental Effects, 34(2), 177-186. https://doi.org/10.1080/15567030903586014

Serin, H. and Akar, N. Y. (2014). The performance and emissions of a diesel engine fueled with tea seed (Camellia sinensis) oil biodiesel-diesel fuel blends. International journal of green energy, 11(3), 292-301. https://doi.org/10.1080/15435075.2013.773434

Sharma, A. and Murugan, S. (2013). Investigation on the behavior of a DI diesel engine fueled with Jatropha Methyl Ester (JME) and Tyre Pyrolysis Oil (TPO) blends. Fuel, 108, 699-708. https:// doi.org/10.1016/j.fuel.2012.12.042

Sharma, A. and Murugan, S. (2015). Combustion, performance and emission characteristics of a DI diesel engine fuelled with non-petroleum fuel: A study on the role of fuel injection timing. Journal of the Energy Institute, 88, 364-75. https://doi.org/10.1016/j.joei.2014.11.006

Sivalakshmi, S. and Balusamy, T. (2014). The performance, combustion, and emission characteristics of neem oil methyl ester and its diesel blends in a diesel engine. Energy Sources, Part A: Recovery, Utilization, and Environmental Effects, 36(2), 142-149. https://doi.org/10.1080/15567036.2011.582614

Srivastava, P. K. and Verma, M. (2008). Methyl ester of karanja oil as alternative renewable source energy. Fuel, 87, 1673-7. https://doi.org/10.1016/j.fuel.2007.08.018

Subhash, L. and Subramanian, K. A. (2014). Impact of nozzle holes configuration on fuel spray, wall impingement and NO x emission of a diesel engine for biodiesel-diesel blend (B20). Applied Thermal Engineering, 64(1), 307314.

Sukumar, P., Jegan, R., Balasubbramanian, K. and Nagarajan, G. (2009). Effect of injection pressure on performance, emission and combustion characteristics of high linolenic linseed oil methyl ester in a DI Diesel engine. Renewable Energy, 34, 1227-33. https://doi.org/10.1016/j.renene.2008.10.001

Suresh, G., Kamath, H. C. and Banapurmath, N. R. (2014). Effects of injection timing, injector opening pressure and nozzle geometry on the performance of cottonseed oil methyl ester-fueled diesel engine. International Journal of Sustainable Engineering, 7(1), 82-92. https:// doi.org/10.1080/19397038.2013.811703

Tao, F., Liu, Y., Rempel Ewert, B. H., Foster, D. E., Reitz, R. D., Choi, D. and Miles, P. C. (2005). Modelling the effect of EGR and retarded injection on soot formation in a high-speed diesel injection (HSDI) diesel engine using a multi-step phenomenological soot model. Society of Automotive Engineers, Paper No: 01-0121.

Tamilselvan, P. and Nallusamy, N. (2017). Reduced emissions using blends of diesel fuel and Chicha oil biodiesel. Energy Sources, Part A: Recovery, Utilization, and Environmental, Effects, 1-6. https://doi.org/10.1080/15567036.2017.1289281

Tumbal, A. V., Banapurmath R. and Tewari, G. (2016). Effect of injection timing, injector opening pressure, injector nozzle geometry, and swirl on the performance of a direct injection, compression-ignition engine fuelled with honge oil methyl ester (home). International Journal of Automotive Technology, 17(1), 35-50. https://doi.org/10.1007/s12239-016-0003-3

Vairamuthu, G., Sundarapandian, S. and Thangagiri, B. (2016). Use of calophyllum inophyllum biofuel blended with diesel in DI diesel engine modified with nozzle holes and its size. Heat Mass Transfer, 52, 1005-1013. https://doi.org/10.1007/s00231-015-1623-2

Venkanna, B. K. and Reddy, C. V. (2011). Performance, emission and combustion characteristics of DI diesel engine running on blends of honne oil/diesel fuel/kerosene/DMC. Int J Agric \& Biol Eng, 4(3), 48-57.

Wategave, S. P., Sawant, M. S., Tandale, M. S., Suresh, G., Yaliwal, V. S., Banapurmath, N. R. and Tewari, P. G. (2014). Effect of injection timing, injector opening pressure and nozzle geometry on the performance of a compression ignition engine operated on non-edibleoil methyl esters from different sources. International Journal of Sustainable Engineering, 7(1), 71-81. https:// doi.org/10.1080/19397038.2013.777134

Williams, P. T. (2013). Pyrolysis of waste tyres: A review. Waste Management, 33, 1714-1728. https://doi.org/10.1016/j.wasman.2013.05.003 